\title{
Educational Environment and its Relation to Nursing Student Academic Achievement
}

\author{
Wafaa Ahmed Abdallah Essa ${ }^{1}$, Sanaa Mohammed Aref ${ }^{2}$, Mona Thabet $^{3}$
}

1- Bachelor of Nursing, Faculty of Nursing, Mnia University,

2- Assist professor of Nursing Administration Department, Faculty of Nursing, Elminia University,

3- Lecturer of Nursing Administration Department, Faculty of Nursing, Elminia University

\begin{abstract}
Background: Educational environment have a significant impact on promoting and enhancing lifelong learning and continuing academic development. Aim: the aim of this study is to evaluate the educational environment and it's relation to nursing student academic achievement among fourth year students at Faculty of Nursing. Design: Descriptive correlational research design was used to achieve the aim of the current study. Setting: Faculty of Nursing, Minia University. Subjects: fourth year nursing students who enrolled for the academic year 2018-2019 $(n=360)$. Tools: one tool was used to collect data pertinent to the study. It was included three parts; personal data, academic achievement of student's final score of $1^{\text {st }}$ semester, and the Dundee Ready Education Environment Measure (DREEM). Results: The findings in the present study revealed that the overall score of DREEM was $85.8 \%$ with mean global score (127.5/200), which indicated that the students have more positive than negative perceptions of their educational environment. Conclusion: The current study explained that students' perception of their educational environment is more positive than negative. It was clear that educational environment does not have an enormous impact on academic achievement of students as commonly perceived. Recommendations: Emphasis on developing students' skill rather than just transfer of factual knowledge, using active learning techniques like small group discussion.
\end{abstract}

Keywords: Educational Environment, DREEM, Nursing students, Academic achievement.

\section{Introduction}

In today's world, education systems constantly must be evolve in order to effectively respond to the rapidly changing demands of the societies they serve. Also, innovations in curricula, methodologies, materials and technologies may require major changes in the design of the educational environments (EE) in which they are housed ${ }^{(1)}$.

In nursing field education, is a fundamental, because nursing service had a vital component of the health care delivery system that reaffirms its purpose as a practical discipline in assisting patients to achieve positive health outcomes. Also, nurses constitute an important element of the medical team; they are the key to quality in health care delivery system. A poorly trained nurse may not only hamper the team's effectiveness but also lead to low quality health care. Therefore, the EE had important relation and influence on nursing student academic achievement ${ }^{(2)}$.

Nursing students will be the future nurses who represent a very important component of the medical team. A poorly graduate nurse might not just hinder the team's effectiveness, additionally cause inferiority health care. Clinical learning lies at the center of nursing education that aids to organize students for the type of work they will be compelled to do as professional nurses; so it is very important to foster their educational environment ${ }^{(3)}$.

Educational environment is not restricted to studentteacher interaction, teaching and learning activities, but also includes having good facilities and physical structures that provided by the institution. Also, the perceptions of students' about the EE has pivotal role in executing modifications of curriculum, learning, and teaching process. It is possible to assess and modify the EE by employing appropriate methods and instruments to assess it ${ }^{(4)}$.

The concept of the educational or learning environment is "the conditions forces, and external stimuli which challenge on the individual, these forces may be physical, social, as well as intellectual forces and conditions". Therefore, the learning environment is an interactive network of forces within the teaching and learning activities that

P a g e $\mid 26$ influence students learning outcomes. Specifically, in nursing education, the learning environment has to be integrated between theory and clinical practice in order to obtain balanced learning outcomes ${ }^{(5)}$.

Educational environment not only has an impact on the students during the academic years; but it has its reflections throughout their career. The Dundee Ready Educational Environment Measure (DREEM) is an internationally accepted useful tool to analyze undergraduate educational environments in the health professionals. This tool enables the faculty to adopt changes in their teaching methods to make the learning process more productive and enjoyable for future students ${ }^{(6)}$.

Thus, the learner's perception of the learning environment determines approach to learning and learning outcome. Appraisal of the learning environment is vital to deliver high quality nursing education. Negative perceptions of the learning environment have a negative impact on the student achievement, satisfaction, and learning outcome. This would result in "fear and anxiety" that may stop up learning while positive perceptions could lead to a feeling of "attraction and interest" which may enhance learning ${ }^{(7)}$.

Students' perception of their EE has progressively attracted more attention and it is always recognized as important to consider the students' perceptions to improve the EE; because students' perceptions are associated positively with learning outcomes, learning approach and attitude toward studying. So, assessment of students' perceptions regarding the EE was believed to assist educators and administration of health professions colleges in gauging the quality of learning (8)

As universities continue to become more student oriented, student perceptions of higher educational facilities and services are becoming increasingly important. Meaningful learning correlates positively with the students' perceptions of the educational environment, which impacts on students' learning experiences and outcomes. It influences how, why and what students learn. The conducive environment has a 
positive and significant impact on students' learning, academic progress (achievement) and well-being ${ }^{(9)}$.

Academic achievement is something students achieve at school, college or university in class, in a laboratory, library or field work ${ }^{(10)}$. The academic achievement refers to the average marks obtained by an individual in the final examination. It has long been recognized as one of the important goals of education encompassing the culture of a faculty and its presiding ethos and characteristics, including how students interact with and treat one another, as well as the ways in which teachers may organize an educational setting to facilitate learning ${ }^{(11)}$.

There are important relationships between learning environment, and students' academic achievement and social emotional outcomes. One of the main qualities of a positive educational environment is to impart students' influence and responsibility over their own learning situation, and thereby increase the likelihood that students would become active learners ${ }^{(12)}$.

\section{Significance of the study}

Nursing as a profession is currently compelled to address the challenges posed by globalization and to respond by forming international alliances that will facilitate knowledge sharing, in order to improve human health. Thus, the education of under graduate nurses is fundamental to these health initiatives ${ }^{(13)}$, because the environment of learning has an impact on the experiences of students and consequences of their academic achievement which in the future affect their practice of nursing profession ${ }^{(14)}$.

The accomplishment and contentment of nursing students depends upon their educational environment. Despite the recent increase in number of nursing colleges in Egypt, the literature review identified little studies about learning environment in Egyptian nursing colleges. As, EL-Gilany, et al., (2017) ${ }^{(15)}$ assessed learning environment from three Faculties of Nursing according to their student perception (Port-said, Benisuif, and Aswan) and revealed that total DREEM mean score of nursing students were (118.4) which is considered to be more positive environment.

\section{Aim of the study:}

The aim of current study was to assess the educational environment and it's relation to nursing student academic achievement among fourth year students at Faculty of Nursing, Minia University.

\section{Research Questions}

- What is the perception of nursing students about their educational environment?

- Is there a relation between perception of nursing students about their educational environment and their academic achievement?

\section{Subjects and Methods \\ Study design: \\ Descriptive correlational research design was used to achieve the aim of the current study.}

\section{Setting:}

The study was conducted at Faculty of Nursing, Minia University in Minia city, Egypt.
Study subject included all undergraduate nursing students of $4^{\text {th }}$ year, at Faculty of Nursing, Minia University; $(n=360)$

Tools for data collection:

Data collected through the utilization of one tool as follow:

Tool (1) - Dundee Ready Education Environment Measure DREEM instrument, it was included three parts as follows:

Part (1): Personal data of the students, it was included information about nurse students. The data was included items related to age, gender, residence, last academic achievement, last certification, and department.

Part (2): The academic achievement: this part was included the student's final total score of $1^{\text {st }}$ semester for $4^{\text {th }}$ academic year. The academic achievement of the students was divided as follows: (Poor; Fair; Good; Very good; and Excellent).

Part (3): The Dundee Ready Education Environment Measure (DREEM) developed by Roff et al., (1997) ${ }^{(16)}$ to measure students' perception of the education climate. The tool included five subscales of the learning environment, which identified as follows: component of students' perception of learning (SPL) consisted of (12 items), students' perception of teachers (SPT) consisted of (11 items), students' academic self-perception (SASP) consisted of (8 items), students' perceptions of atmosphere (SPA) consisted of (12 items), and students' social self-perceptions (SSSP) possessed (7 items).

\section{Scoring system of the Dundee Ready Education Environment Measure DREEM instrument:}

Items were scored on 5-point Likert scale as follows: $4=$ strongly agree, $3=$ agree, $2=$ unsure, $1=$ disagree, and $0=$ strongly disagree. However, 9 of the 50 items (number 4, 8, 9, $17,25,35,39,48$ and 50) are negatively phrased statements and were scored reversely.

The tool was ranged from ( 0 to 200) as higher score, the higher perception of positive school environment climate. The Practical Guide described by McAleer and Roff ${ }^{(17)}$ for interpreting the overall and subscale scores, and the number of items in each subscale is given as follows:

- Students' Perception of Learning ranged as: (very poor, teaching is viewed negatively, a more positive perception, and teaching highly thought).

- Students' perception of course organizers ranged as: (abysmal, in need of some retraining, moving in the right direction, and model course organizers).

- Students' Academic Self-Perception ranged as: (feelings of total failure, many negative aspects, feeling more on the positive side, and confident).

- Students' Perceptions of Atmosphere ranged as: (a terrible environment, there are many issues that need changing, a more positive attitude, and a good feeling overall).

- Students' Social Self Perceptions ranged as: (miserable, not a nice place, not too bad, and very good socially).

- Overall ranged as: (very poor environment, plenty of problems in the environment, more positive than negative environment, and excellent environment. 


\section{Reliability of tools:}

The tool was tested and demonstrated good internal reliability with Cronbach' alpha test. The alpha coefficient reliability for the Dundee Ready Education Environment Measure was $(\alpha=0.884)$. And for subscales were as follow (SPL) was $(\alpha=0.710)$, (SPT) was $(\alpha=0.618)$, (SASP) $(\alpha$ $=0.764),($ SPA $)$ was $(\alpha=0.723)$, and $(\operatorname{SSSP})$ was $(\alpha=0.695)$.

\section{Pilot study:}

A pilot study was conducted on $10 \%$ of participants which equal (36) nursing students to ascertain the clarity, comprehensiveness and applicability of the tools as well as to estimate the appropriate time required to fill the questionnaire. Based on pilot study there was no modification done, and it was added to final results.

\section{Study procedure}

- Written approvals were obtained from administrative authorities (Faculty dean, Vice dean for teaching and student affairs, and head of departments of the Faculty of Nursing, Minia University) after explaining the purpose of the study.

- The questionnaires was distributed to all of the undergraduate nursing students after explaining the purpose and process of data collection. Questionnaires was directly administered and supervised by the researcher with the help of instructors from Administration, Psychiatry and Community Departments.

- Students were given from 15 minute to 30 minute to answer the questionnaires. Students were not allowed to discuss with each other to save time and to be given the most accurate answer from the researcher but they were allowed to ask questions to the researcher about the meaning of statements or educational terms in the questionnaire.

- The data collection was performed to the $4^{\text {th }}$ year nursing students during first semester of the academic year 2018/2019.

- The data was collected during the days of practical training (Tuesday, Wednesday, and Thursday) to have the largest number of students.

\section{Ethical considerations}

- An oral consent was obtained from students to collect the study data before data collection. After explanation of the purpose of the study, the privacy and confidentiality of the answers were guaranteed by the researcher.

- Each assessment sheet was coded and participants' names not appeared on the sheets for the purpose of anonymity and confidentiality.

- The participants were informed that their participation in the study was completely voluntary and there was no harm if they are not participate in the study.

\section{Statistical analysis:}

The data obtained from the study tools were categorized, tabulated, analyzed and data entry was performed using the SPSS software (statistical package for social sciences version (25.0). Descriptive statistics were applied (e.g. mean, standard deviation, frequency and percentage). Pearson's correlation coefficient was applied between quantitative variables. A significant level value was considered when $\mathrm{P}<0.05$.

\section{Results}

Table (1): Percentage distribution of personal data among nurse students

\begin{tabular}{|c|c|c|c|}
\hline \multirow{2}{*}{\multicolumn{2}{|c|}{ Personal data }} & \multicolumn{2}{|c|}{ Nurse Students $(n=360)$} \\
\hline & & No. & $\%$ \\
\hline \multicolumn{4}{|l|}{ Age } \\
\hline$\bullet$ & $20-21$ & 138 & 38.4 \\
\hline$\bullet$ & $22-23$ & 222 & 61.6 \\
\hline \multicolumn{2}{|r|}{ Mean \pm SD } & \multicolumn{2}{|c|}{$21.7 \pm .7$ years } \\
\hline \multicolumn{2}{|c|}{ Gender } & & \\
\hline • & Male & 143 & 39.7 \\
\hline$\bullet$ & Female & 217 & 60.3 \\
\hline \multicolumn{4}{|c|}{ Residence } \\
\hline • & Rural & 281 & 78.1 \\
\hline$\bullet$ & Urban & 79 & 21.9 \\
\hline \multicolumn{4}{|c|}{ Last academic achievement } \\
\hline$\bullet$ & Poor & 9 & 2.5 \\
\hline$\bullet$ & Good & 99 & 27.5 \\
\hline$\bullet$ & Very good & 175 & 48.6 \\
\hline$\bullet$ & Excellent & 77 & 21.4 \\
\hline \multicolumn{4}{|c|}{ Last certification } \\
\hline$\bullet$ & Secondary school & 301 & 83.6 \\
\hline$\bullet$ & Clinical nursing institution & 59 & 16.4 \\
\hline \multicolumn{4}{|c|}{ Department } \\
\hline$\bullet$ & Nursing Administration department & 88 & 24.4 \\
\hline$\bullet$ & Psychiatric Nursing department & 86 & 23.9 \\
\hline$\bullet$ & Community Nursing department & 186 & 51.7 \\
\hline
\end{tabular}

Table (1) shows that the highest percent of nursing students (61.6\%) were in the age group (22-23) with mean age $(21.7 \pm 0.70)$, and highest percent of them $(60.3 \%)$ were females. Regarding to residence, more than three quarters of nursing students $(78.1 \%)$ were lived in rural. Connecting to last academic achievement, the highest percentage of nursing students had "very good" $(48.6 \%)$. Regarding to last certification, more than three quarters of nursing students $(83.6 \%)$ enrolled in Faculty of Nursing from secondary school. Speaking about academic department, more than half of nursing students (51.7\%) were in Community Nursing department. 
Minia Scientific Nursing Journal (Print) (ISSN 2537-012X) Vol. (7) No. (1) June 2020

Table (2): Percentage distribution of nursing students about their educational environment subscales $(n=360)$

\begin{tabular}{|c|c|c|}
\hline \multirow[t]{2}{*}{ Educational Environment subscales } & \multicolumn{2}{|c|}{ Nursing students $(n=360)$} \\
\hline & No & $\%$ \\
\hline \multicolumn{3}{|l|}{ Students Perception of Learning } \\
\hline Very poor & 3 & 0.8 \\
\hline Teaching is viewed negatively & 34 & 9.5 \\
\hline A more positive perception & 280 & 77.8 \\
\hline Teaching highly thought of & 43 & 11.9 \\
\hline \multicolumn{3}{|l|}{ Students Perception of Course organizers } \\
\hline Abysmal & 1 & 0.3 \\
\hline In need of some retraining & 58 & 16.1 \\
\hline Moving in the right direction & 297 & 82.5 \\
\hline Model course organizers & 4 & 1.1 \\
\hline \multicolumn{3}{|l|}{ Students' ${ }^{\prime}$ Academic Self-Perception } \\
\hline Feelings of total failure & 3 & 0.8 \\
\hline Many negative aspects & 32 & 8.9 \\
\hline Feeling more on the positive side & 182 & 50.6 \\
\hline Confident & 143 & 39.7 \\
\hline \multicolumn{3}{|l|}{ Students Perceptions of Atmosphere } \\
\hline A terrible environment & 6 & 1.7 \\
\hline There are many issues that need changing & 56 & 15.6 \\
\hline A more positive attitude & 255 & 70.8 \\
\hline A good feeling overall & 43 & 11.9 \\
\hline \multicolumn{3}{|l|}{ Students' Social Self Perceptions } \\
\hline Miserable & 2 & 0.6 \\
\hline Not a nice place & 54 & 15.0 \\
\hline Not too bad & 243 & 67.5 \\
\hline Very good socially & 61 & 16.9 \\
\hline
\end{tabular}

Table (2) reveals that more than three quarters (77.8\%) of nursing student had a more positive perception regarding the" learning perception domain". About the "student perception of course organizer (teacher)" it was noted that majority of nursing student $(82.5 \%)$ perceived their teachers as moving to the right direction. Regarding the" Academic Self-Perception" domain more than half of nursing students (50.6\%) feeling more on the positive side and more than one third (39.7\%) of them feel confident .Moving to "students perceptions of atmosphere " the highest percent of nursing students ( $70.8 \%$ ) had a more positive attitude toward their educational atmosphere. Connecting to the "Social Self Perceptions" domain more than two thirds of nursing students $(67.5 \%)$ had social perception not too bad.

Table (3): Mean scores of student perception about educational environment and its subscale

\begin{tabular}{|l|c|c|c|}
\hline \multicolumn{1}{|c|}{ Educational Environment } & \multicolumn{2}{c|}{ Student perception (n=360) } \\
\cline { 2 - 4 } & Mean+ SD & Min & Max \\
\hline Students Perception of Learning & $31.3 \pm 5.1$ & 8.0 & 41.0 \\
\hline Students Perception of Course organizers & $25.5 \pm 3.6$ & 11.0 & 37.0 \\
\hline Students' Academic Self-Perception & $22.8 \pm 4.8$ & 0.0 & 32.0 \\
\hline Students Perceptions of Atmosphere & $29.9 \pm 6.0$ & 3.0 & 46.0 \\
\hline Students' Social Self Perceptions & $18.0 \pm 3.7$ & 4.0 & 27.0 \\
\hline \multicolumn{1}{|c|}{ Overall } & $\mathbf{1 2 7 . 5 \pm 1 8 . 4}$ & $\mathbf{3 6 . 0}$ & $\mathbf{1 6 5}$ \\
\hline
\end{tabular}

Table (2) shows that the students had mean score for students' perception of learning $(31.3 \pm 5.1)$; for students perception of course organizers $(25.5 \pm 3.6)$; for students' academic self-perception $(22.8 \pm 4.8)$; for students perceptions of atmosphere $(29.9 \pm$ $6.0)$; and for students' social self- perceptions $(18.0 \pm 3.7)$. The total mean score of overall score of educational environment was $(127.5+18.4)$ with min score (36) and max score (165).

Table (4): Relation between levels of nursing students' perception regarding Educational Environment subscales and their level of academic achievement

\begin{tabular}{|c|c|c|c|c|c|c|c|c|c|c|c|c|}
\hline \multirow{3}{*}{$\begin{array}{l}\text { Dundee Ready Education } \\
\text { Environment Measures }\end{array}$} & \multicolumn{10}{|c|}{ Student levels of academic achievement $(n=360)$} & \multirow{3}{*}{ FEP } & \multirow{3}{*}{$\begin{array}{c}P- \\
\text { value }\end{array}$} \\
\hline & \multicolumn{2}{|c|}{$\begin{array}{c}\text { Excellent } \\
(n=47)\end{array}$} & \multicolumn{2}{|c|}{$\begin{array}{l}\text { V.good } \\
(n=150)\end{array}$} & \multicolumn{2}{|c|}{$\begin{array}{c}\text { Good } \\
(\mathrm{n}=119)\end{array}$} & \multicolumn{2}{|c|}{$\begin{array}{c}\text { Fair } \\
(n=39)\end{array}$} & \multicolumn{2}{|c|}{$\begin{array}{l}\text { Poor } \\
(n=5)\end{array}$} & & \\
\hline & No & $\%$ & No & $\%$ & No & $\%$ & No & $\%$ & No & $\%$ & & \\
\hline \multicolumn{13}{|c|}{ Students' Perception of Learning } \\
\hline Very poor & 1 & 2.1 & 1 & 0.7 & 1 & 0.8 & 0 & 0.0 & 0 & 0.0 & \multirow{4}{*}{10.158} & \multirow{4}{*}{0.602} \\
\hline $\begin{array}{l}\text { Teaching is viewed } \\
\text { negatively }\end{array}$ & 8 & 17.0 & 14 & 9.3 & 7 & 5.9 & 5 & 12.8 & 0 & 0.0 & & \\
\hline A more positive perception & 31 & 66.0 & 115 & 76.7 & 98 & 82.4 & 31 & 79.5 & 5 & 100 & & \\
\hline Teaching highly thought of & 7 & 14.9 & 20 & 13.3 & 13 & 10.9 & 3 & 7.7 & 0 & 0.0 & & \\
\hline \multicolumn{13}{|c|}{ Students' Perception of Course organizers } \\
\hline Abysmal & 0 & 0.0 & 1 & 0.7 & 0 & 0.0 & 0 & 0.0 & 0 & 0.0 & \multirow{4}{*}{12.236} & \multirow{4}{*}{0.427} \\
\hline In need of some retraining & 8 & 17.0 & 30 & 20.0 & 14 & 11.8 & 6 & 15.4 & 0 & 0.0 & & \\
\hline $\begin{array}{l}\text { Moving in the right } \\
\text { direction }\end{array}$ & 37 & 78.7 & 117 & 78.0 & 105 & 88.2 & 33 & 84.6 & 5 & 100 & & \\
\hline Model course organizers & 2 & 4.3 & 2 & 1.3 & 0 & 0.0 & 0 & 0.0 & 0 & 0.0 & & \\
\hline \multicolumn{13}{|c|}{ Students' Academic Self-Perception } \\
\hline Feelings of total failure & 1 & 2.1 & 1 & 0.7 & 1 & 0.8 & 0 & 0.0 & 0 & 0.0 & \multirow{2}{*}{13.955} & \multirow{2}{*}{0.304} \\
\hline Many negative aspects & 4 & 8.5 & 20 & 13.3 & 8 & 6.7 & 0 & 0.0 & 0 & 0.0 & & \\
\hline
\end{tabular}


Minia Scientific Nursing Journal (Print) (ISSN 2537-012X) Vol. (7) No. (1) June 2020

\begin{tabular}{|c|c|c|c|c|c|c|c|c|c|c|c|c|}
\hline \multirow{3}{*}{$\begin{array}{l}\text { Dundee Ready Education } \\
\text { Environment Measures }\end{array}$} & \multicolumn{10}{|c|}{ Student levels of academic achievement $(n=360)$} & \multirow{5}{*}{ FEP } & \multirow{5}{*}{$\begin{array}{c}P- \\
\text { value }\end{array}$} \\
\hline & \multicolumn{2}{|c|}{$\begin{array}{c}\text { Excellent } \\
(n=47)\end{array}$} & \multicolumn{2}{|c|}{$\begin{array}{l}\text { V.good } \\
(n=150)\end{array}$} & \multicolumn{2}{|c|}{$\begin{array}{c}\text { Good } \\
(n=119)\end{array}$} & \multicolumn{2}{|c|}{$\begin{array}{c}\text { Fair } \\
(n=39)\end{array}$} & \multicolumn{2}{|c|}{$\begin{array}{l}\text { Poor } \\
(n=5)\end{array}$} & & \\
\hline & No & $\%$ & No & $\%$ & No & $\%$ & No & $\%$ & No & $\%$ & & \\
\hline $\begin{array}{l}\text { Feeling more on the } \\
\text { positive side }\end{array}$ & 25 & 53.2 & 76 & 50.7 & 59 & 49.6 & 21 & 53.8 & 1 & 20.0 & & \\
\hline Confident & 17 & 36.2 & 53 & 35.3 & 51 & 42.9 & 18 & 46.2 & 4 & 80.0 & & \\
\hline \multicolumn{13}{|c|}{ Students' Perceptions of Atmosphere } \\
\hline A terrible environment & 1 & 2.1 & 3 & 2.0 & 2 & 1.7 & 0 & 0.0 & 0 & 0.0 & \multirow{4}{*}{12.075} & \multirow{4}{*}{0.440} \\
\hline $\begin{array}{l}\text { There are many issues that } \\
\text { need changing }\end{array}$ & 9 & 19.1 & 23 & 15.3 & 16 & 13.4 & 8 & 20.5 & 0 & 0.0 & & \\
\hline A more positive attitude & 35 & 74.5 & 106 & 70.7 & 82 & 68.9 & 29 & 74.4 & 3 & 60.0 & & \\
\hline A good feeling overall & 2 & 4.3 & 18 & 12.0 & 19 & 16.0 & 2 & 5.1 & 2 & 40.0 & & \\
\hline \multicolumn{13}{|c|}{ Students' Social Self Perceptions } \\
\hline Miserable & 0 & 0.0 & 1 & 0.7 & 1 & 0.8 & 0 & 0.0 & 0 & 0.0 & \multirow{4}{*}{7.499} & \multirow{4}{*}{0.823} \\
\hline Not a nice place & 7 & 14.9 & 26 & 17.3 & 16 & 13.4 & 5 & 12.8 & 0 & 0.0 & & \\
\hline Not too bad & 30 & 63.8 & 98 & 65.3 & 81 & 68.1 & 31 & 79.5 & 3 & 60.0 & & \\
\hline Very good socially & 10 & 21.3 & 25 & 16.7 & 21 & 17.7 & 3 & 7.7 & 2 & 40.0 & & \\
\hline
\end{tabular}

\section{FEP: P value based on Fisher exact probability}

Table (4) reveals that the highest percentage of nursing students of all academic achievement levels (poor, fair, good, v. good, and excellent) perceive all educational environment subscale as more positive than negative environment with no statistical significant relation between student level of academic achievement and their perception about educational environment subscales.

\section{Discussion}

Educational environment (EE) is the "culture" that determines students' learning development. In classrooms, clinical wards, and community health centers, students' learning scaffolding and development take place when interactions between students and teachers, peers, and other health care professionals occur. With the existence of friendships (high affiliation) and teacher support in classrooms, students' level of learning would be improved ${ }^{(18)}$.

Educational environment (EE) refers to the diverse physical locations, contexts, and cultures in which students learn. It includes perception of infrastructure of the campus, learning opportunities, teacher's skills and attitudes and their interaction with peers as well as many other factors. Studies had shown that the EE affects students' achievement, happiness, motivation, and success. The quality of the EE is indicative of the effectiveness of an educational program ${ }^{(15)}$.

Educational environment makes an important contribution to student learning, it have greatly impact on students satisfaction with the course of study, perceived wellbeing and academic achievement. The educational environment can also be changed; thus enhancing the quality of the environment for the nursing education process itself ${ }^{(5)}$.

Also, the learning experience in a nursing faculty can bring about a lifelong change in the students' knowledge, attitudes, and practices. The teacher's role is to facilitate learning by providing content and a positive learning environment. Understanding student's perceptions about the EE plays a vital role in planning and implementing a holistic curriculum ${ }^{(24)}$.

The Dundy Ready Educational Environment Measure (DREEM) can provide useful diagnostic information about medical and nursing faculties, whether it is in developing or western developed countries. The DREEM gives a clear indication of the priorities for reform of the curriculum. These data can also serve as a baseline for a longitudinal quality assessment of student's perceptions of the changes that planned for the college ${ }^{(19)}$. DREEM can also be used to pinpoint more specific strengths and weaknesses within the educational environment. This reflects a better EE in the studied colleges. And this could be attributed to the on-going quality assurance and accreditation programs implemented in all Egyptian Universities ${ }^{(15)}$. Also, (DREEM) has been used internationally for different purposes and is regarded as a useful tool by users ${ }^{(20)}$.

Regarding the personal data of nursing students, the highest percent of nursing students $(61.6 \%)$ were in age group (22-23), and highest percent of them $(60.3 \%)$ were female. Regarding to residence, more than three quarter of nursing students $(78.1 \%)$ were lived in rural. Connecting to last academic achievement, the highest percent of nursing students had "very good" (48.6\%). Regarding to last certification, more than three quarter of nursing students $(83.6 \%)$ were enrolled in Nursing Faculty from secondary school. Speaking about department, more than half of nursing students $(51.7 \%)$ were in community department.

Regarding the overall score of DREEM; the current study was revealed that students' perception about overall score was $85.8 \%$ with mean score $(127.5 / 200)$ which indicated to more positive than negative environment; and which means that the academic educational environment can still be improved to benefit the nursing students.

This results may be due to the many reasons, as the Faculty of Nursing, Minia University was seeking for accreditation and this required the administrative authority to support educational environment for students with effective materials and supplies; the nursing curriculums that provided to students were more up to date and dependent on students centered than teacher centered; teachers are knowledgeable and have effective communication skills; the effective relations between faculty staff members' and students; and the support that provided to students during stressful situations ;and encouraging students to participate in teaching sessions ;and the atmosphere is relaxed and motivate students during sessions.

This result was the highest one in the studies done in Egypt until now. As; El-Gilany, et.al, (2017) ${ }^{(15)}$, reported that the total DREEM mean score among nursing students at (Faculty of Nursing, Port Said University; Faculty of Nursing, Ben-Suif University, and Faculty of Nursing, Aswan University) was (118.4). Also, Abusaad et al., (2015) ${ }^{(14)}$, had a study on nursing students and reported total mean score for pediatric and maternity nursing students' perception of their learning environment were 115.0 and 110.3 respectively. In addition Youssef, et al, $\mathbf{2 0 1 3}^{(21)}$, reported that total mean score of all six years at the Faculty of Medicine, Suez Canal University was (113.8). 
On the international side there were many studies reported more positive than negative environment; as in Saudi Arabia El-Sobkey, (2015) ${ }^{(8)}$ had a study on medical students and showed the significant higher perception of the educational environment at the new campus than the old one (mean score for the DREEM total mean score were (152.1 and 127.7) respectively, $\mathrm{P}=0.0001)$. Also in Sweden, Edgren, et al. (2010) ${ }^{(22)}$ had high mean score $(145 / 200)$ was congruent with current study result; as they used DREEM for comparing the educational environment at two different stages of curriculum reform. The students rated their climate as positive.

Also in Malaysia, Ugusman, et al. (2015) ${ }^{(23)}$ had an assessment of learning environment among the first year of Malaysian medical students; and revealed that the total DREEM score recorded was (135.6/200), which indicated that medical students' perceptions were more positive than negative. Moreover in India Patil and Chaudhari (2016) ${ }^{(24)}$, revealed from their study that all students perceived their EE positively. The mean global DREEM score was (123/200).

In Sudan, this result was in same line with Ahmed, et al. (2018) ${ }^{(25)}$ carried study about students' perception of the learning environment and its relation to their study year and performance in Sudan. They mentioned that the overall score of students' perception was (122/200), which indicating a positive perception of the learning environment.

Moreover in United Arab Emirates, Nosair, et al. (2015) (18) carried out a study about measuring students' perceptions of educational environment in the PBL Program of Sharjah Medical College; and revealed that the PBL environment is generally perceived positively by their medical students. The overall DREEM mean score was (113.4/200).In Pakistan, Noreen, et al. (2018) ${ }^{(26)}$ displayed that over all DREEM mean score was $(107.5 / 200)$.

In Turkey Tontuş, (2010) ${ }^{(27)}$, mentioned from study results that undergraduate medical school students from the 11different medical faculties all over Turkey had overall total DREEM mean score for a group of 11 medical faculties was (107.15/200) which lined with "more positive than negative environment" as the current study result.in Iran, this result was congruent with Arab, et al. (2016) ${ }^{(28)}$ who done a study about Nursing and Midwifery students perception of educational environment; and revealed that the mean total DREEM mean score was $(103.54 / 200)$.

Also this was in line with Dreyer, et al. (2015) ${ }^{(29)}$ in South Africa who carried study about clinical associate students' perception of the educational environment at the University of the Witwatersrand, Johannesburg; the students' perceptions of their learning environment were 'more positive' than negative. In Sri Lanka, Lokuhetty, et al. (2010) ${ }^{(30)}$, carried study about students' perception of the educational environment in a Medical Faculty with an innovative curriculum in Sri Lanka. The majority (65.6\%) responded "more positively" toward their educational environment. In Bangladesh, Mohsena, et al. (2016) ${ }^{(31)}$ carried study and suggested that students, in general, hold positive perceptions of their course environment. These results can serve as a baseline for a longitudinal quality assessment of pupils' perceptions of the college.

While the current study results were in disagreement with Helal, et al. (2013) ${ }^{(9)}$ who conducted a study in Egypt about Quality of educational environment among Egyptian medical students using DREEM questionnaire. The study revealed that the total mean score was (92.6) out of a maximum of $200(46.3 \%)$ indicating plenty of problems so improvement is required across all five domains of the educational environment.

Also, the current study results were in congruent with Sharkawy et al., (2013) ${ }^{(5)}$, reported about two thirds $(65.9 \%)$ of nursing students at Assiut, Sohag, and Qena had poor level of perception. And Al-Ayed and Sheik, (2008) ${ }^{(32)}$ had assessment of the educational environment at the College of Medicine of King Saud University, Riyadh; and the results showed a low overall score on the DREEM inventory: a score of $45.0 \%(89.9 / 200)$.

Moreover, the current study revealed that students had had high mean score and levels for all subscale of DREEM as: for students' perception of learning (SPL), the highest percent of students perceived their environment as "more positive perception", with mean score $(31.3+5.1)$. For the students' perception of teachers (SPT) the highest percent of students perceived their environment as "Moving in the right direction" with mean score $(25.5 \pm 3.6)$. For students' academic self-perception (SASP) the highest percent of students perceived their environment as "Feeling more on the positive side" with mean score $(22.8 \pm 4.8)$. For students' perceptions of atmosphere (SPA) the highest percent of students perceived their environment as "more positive attitude" with mean score $(29.9 \pm 6.0)$. And for students' social self-perceptions (SSSP) the highest percent of students perceived their environment as "Not too bad" with mean score $(18.0 \pm 3.7)$

Which supported by Al-Qahtani, (2015) ${ }^{(33)}$ the mean scores for all five domains fell within the satisfactory range. This indicates that students perceived" more positive approach" (28.5/48) for their learning; had a "more positive attitude" (21.1/32) toward their academic self-perception; felt their teachers were "moving in the right direction" (25.8/44); had "more positive perception" of their learning environment (27.6/48); and regarded their social self-perception as being "not too bad" (15.7/28).

Also, Ganvir \& Ganvir, (2016) ${ }^{(34)}$ supported the current result. Overall subscale analysis score for the component Student Perception of Learning (SPOL) was (33.9) which are considered to be positive. Subscale of Students' Academic Self-perception (SASP) scored (23.2) which indicate a feeling more on positive side, subscale of Student's perception of Atmosphere (SPOA) scored (32.3) indicating a more positive attitude, and a subscale of students social selfperception had a score of (17.8) which means "not too bad "; but not agreed with subscale Student Perception of Teachers (SPOT) was (30.6) which is interpreted as Model course organizers. Unlike our students which felt their teachers were "moving in the right direction" with mean score (25.5+3.6).

Mushtaq, et al.(2017) ${ }^{(6)}$ agreed to current results of DREEM subscales which were the students' perception of five sub-scales of the educational environment were Student's perception of learning $(29.084 \pm 6.02)$ "more positive perception". Student's perception of course organizers (24.74 \pm 4.93$)$ "Moving in the right direction". Student's academic self-perception (20.9 \pm 4.88$)$ "Feeling more on positive side". Student's perception of atmosphere (29.84 \pm 6.62$)$ was "more positive attitude". Student's social self-perception (17.43 \pm 4.07$)$ "Not too bad".

Moreover, this finding supported by El-Gilany, et al. (2017) ${ }^{(15)}$ who mentioned that the student perception of learning, teachers, academic self-perception and social selfperception were (more positive perception), (moving to the 
right direction), (feeling more on the positive side), students' social self-perceptions (not too bad). But students' perceptions of atmosphere was (there are many issues need changes), while in the current study students' perceptions was "more positive attitude".

In Iran Arab, et al. (2016) ${ }^{(28)}$ done a study about Nursing and Midwifery students perception of educational environment; and revealed the scores for domains were agreed in current study except" Social self-perceptions" in which Iranian students had perception of "Not a nice place" with percent $64 \%$; while the current study the highest percent of students perceived their environment as "Not too bad" with mean score $(18.0 \pm 3.7)$.

The current study revealed that highest percentage of nursing students $(41.7 \%)$ had very good degree of academic achievement; and one third (33.1\%) had good degree; while only $(13.1 \%)$ of them had excellent degree. Nouh, et al. (2016) ${ }^{(35)}$ found that mean GPA of students perceiving their learning environment as "More Positive than Negative" and "Excellent" was 0.38 (95\% confidence interval [CI]0.19 0.57) points higher than those perceiving their learning environment as "Plenty of Problems" and "Poor", adjusting for age, gender, nationality and medical college.

Also, the current study revealed that there is no statistical significant relation between student perception about educational environment and their academic achievement. This result may be due to the nature of the faculty of nursing courses and studies as the students mainly focus on practicing and mastering nursing skills than their environment and classrooms. Most of students preferred to be good nurse and acquired the nursing skills that will help $\mathrm{him} / \mathrm{her}$ to work than to have higher academic achievement.

This was in same line with Baig (2015) ${ }^{(36)}$ who found that academic achievement does not have an enormous impact on the mind-set of students as commonly perceived. This could be attributable to the fact that majority of the students, instead of competing for marks, aimed to compete for practical expertise. On the other side, Al-Qahtani, 2015 ${ }^{(33)}$ found a correlation analysis between learning environment subscales and academic achievement shows that there is a positive and significant relationship between academic achievement and student academic perceptions (SAP) $(\mathrm{r}=0.232, \mathrm{P}=0.004)$. This suggests that students who have a higher GPA are more likely to exhibit higher scores on the SAP subscale.

\section{Conclusion:}

It can be concluded from the current study that overall score of students perception about educational environment (DREEM) was $85.8 \%$ (127.5/200) which indicated that the nursing students had more positive than negative environment perception; and which means that the academic educational environment can still be improved to benefit the nursing students. Also, the highest percentage of students had very good level of academic achievement.

Moreover, there was no statistical significant relation between student level of academic achievement and their perception about educational environment. This study identified major defects and areas that need to be improved in order to facilitate student learning.

Remedial measures need to be implemented in low scoring areas to ensure a sound educational environment for nursing students. This will help improve academic performance as well as personal growth, two of the most important aspects of becoming successful nurse.

Consequently, the study strongly suggests presenting these results to the relevant educational and administrative authorities and decision makers for utilizing them as the basis for strategic planning and resource utilization. In addition, the results should be used as guidance to institutional corrective actions regarding the students' perception of areas of concern.

Recommendations: According to the results of the current study, the following recommendations are suggested:

- Emphasis on developing students' skill rather than just transfer of factual knowledge, using active learning techniques like small group discussion.

- Teachers should try to correlate the facts in the books with the real case scenario, so that students would not feel that the teachings over emphasized factual learning.

- Teachers should not ridicule their students instead they should actively engage them in learning and they should reflect whatever they learn.

- Teachers should be more approachable and flexible while dealing with the students so that students would not feel as if the teachers were authoritarian.

\section{References}

1. Bernard JE. A place to learn: lessons from research on learning environments. $1^{\text {st }}$ ed. Montreal, Canada: UNESCO Institute for Statistics, 2012, 77p.

2. Ali WG, El Banan SHA, Al Seraty\& WH. Effective Clinical Learning Environment as Perceived by Nursing Students at AL Dawadmi, Applied Medical Sciences college: Actual versus Preferred Characteristics. I J N D , 2015; 5 (5):1-6.

3. Ibrahim A AE M, sleem W F . Developing and Validating Standards for Clinical learning Environment at Nursing Faculty. I J I E R. 2017 ; 5(10):51-64.

4. Bhosale U. Medical students' perception about the educational environment in western Maharashtra in medical college using DREEM scale. JCDR, 2015;9 (11):JC01.

5. Sharkawy S A, El-Houfey AA, \& Hassan AK. Students' Perceptions of Educational Environment in the Faculties of Nursing at Assuit, Sohag and South Valley Universities . Ass. Univ. Bull. Environ. Res, 2013;16(2).

6. Mushtaq R, Ansar A, Bibi A, Ramzan M, Munir A, Zaheer A \& Barlas A. Quality of Educational Environment at WAH medical college: assessment by using Dundee Ready Educational Environment Measure. J Ayub Med Coll Abbottabad, 2017; 29(3): 441-4.

7. Ahmed Y A A. Medical Students' Perception of the Learning Environment at the Faculty of Medicine, University of Gezira, Sudan (2016-2017) (Doctoral dissertation, University of Gezira), 2018.

8. El-Sobkey SB. Effect of a new campus, educational level, and instructional mode on the students' perceptions of educational environment of physical therapy program, King Saud University. P Y R X . J . E d u . R e s . R e v, 2015;1 (3) :17-30.

9. Helal R, El-Masry R \& El-Gilany A. Quality of educational environment among Egyptian medical students using DREEM questionnaire. WJMER , 2013; 3(1): 6-14.

10. Kurshid F, Tanveer A \& Qasmi F N. relationship between study habits and academic achievement among hostel living and day scholars' university students. B J H S S, $2012 ; 3(2): 34$.

11. Ibem E O, Owoseni A O, \& Alagbe O A. A study of students' perception of the learning environment :case 
study of department of agriculture, covenant university, , OTA OGUN state, 2017.

12. Al Sheikh MH. Educational environment measurement, how is it affected by educational strategy in a Saudi medical school? A multivariate analysis. J T U Med Sc, 2014; 9(2): 115-22.

13. Hamid B, Farouk A, Hossein B. Nursing students perceptions of their educational environment based on DREEM model in an Iranian university. Malays J Med Sci ,2013;20(4):56-63.

14. Abusaad F, Mohamed H, EL-gilany A. Nursing student's perceptions of the educational learning environment in pediatric and maternity courses using DREEM questionnaire. Journal of Education and Practice, $2015 ; 6(29): 26-32$.

15. El-gilany A, El - bastawesy S, El-sherbeny E, Ibrahim M. under graduate nursing student's perception of educational environment : national study in Egypt . IOSR-JNHS, 2017 ; 6(6): 66-71.

16. Roff S, Mc Aleer S, M Harden R, Al - Qahtani M, Ahmed A U, Deza H, Groenen G, Primparyon P,. Development and Validation of the Dundee Ready Educationa Environment Measure (DREEM).Med Teach, 1997;19(4): 295.

17. McAleer S, Roff S. Part 3: A practical guide to using the Dundee Ready Education Measure (DREEM). AMEE Medical Education Guide No.23 curriculum, environment, climate, quality and change in medical education; a unifying perspective. Edited by Genn JM. Dundee, UK: Asociation of Medical Education in Europe; 2002.

18. Nosair E, Mirghani Z, \& Mostafa R M. Measuring students' perceptions of educational environment in the PBL program of Sharjah Medical College. J Med Edu Curric Dev, 2015 ; 2: 71-9.

19. Makhdoom N M. Assessment of the quality of educational climate during undergraduate clinical teaching years in the college of medicine, Taibah University. J T U Med Sc, $2009 ; 4(1): 42-52$.

20. Miles S, \& Leinster S J. Medical students' perceptions of their educational environment: expected versus actual perceptions. Med edu, 2007 ; 41(3): 265-72.

21. Youssef W, El-Wazir Y M, Ghaly M S \& El-Khadragy R A. Evaluation of the learning environment at the faculty of medicine, Suez Canal University: Students' perceptions. Intel Prop Rights, $2013 ; 1(102)$ : 1-7.

22. Edgren G, Haffling A C, Jakobsson U L F, Mcaleer S \& Danielsen N. Comparing the educational environment (as measured by DREEM) at two different stages of curriculum reform. Med teach, 2010 ;32(6): e233-e8.

23. Ugusman A, Othman N A, Razak Z N A, Soh M M, Faizul P N K \& Ibrahim S F. Assessment of learning environment among the first year Malaysian medical students. J T U Med Sc, 2015;10(4): 454-60.
24. Patil AA \& Chaudhari, VL. Students' perception of the educational environment in medical college: a study based on DREEM questionnaire. Korean J Med Edu, 2016;28(3), 281-8.

25. Ahmed Y, Taha MH, Al-Neel S \& Gaffar A M. Students' perception of the learning environment and its relation to their study year and performance in Sudan. I J M E, 2018; 9, 145-50.

26. Noreen K, Khan KA, \& Nehra R A. Students' Perception Of Learning Environment using Dundee Ready Educational Environment Measure( DREEM )Inventory. Pakistan. P J P H ,2018; 8(2): 112-6.

27. Tontuş H Ö. DREEM; dreams of the educational environment as its effect on education result of 11 Medical Faculties of Turkey. Journal of experimental and clinical medicine, $2010 ; 27(3)$ : 104-8.

28. Arab M, Rafiei H, Safarizadeh M H, Safarizadeh M M, Shojaei N, Mehdi M. Nursing and midwifery students perception of educational environment: A Cross Sectional Study in Iran. IOSR 2016 ; 5(1):64-7.

29. Dreyer A, Gibbs A \& Mlambo M. Clinical Associate students' perception of the educational environment at the University of the Witwatersrand, Johannesburg. African journal of P H C F M, 2015 ; 7(1), 1-8.

30. Lokuhetty M D S, Warnakulasuriya S P ,Perera RIR, De Silva HTR and Wijesinghe HD. Students' perception of the educational environment in a Medical Faculty with an innovative curriculum in Sri Lanka. University of Colombo, Sri Lanka. S E A J M E, 2010;4 (1), 9-15.

31. Mohsena M, Debsarma S, \& Haque M. Determining the Quality of Educational Climate in a Private Medical College in Bangladesh via the 'Dundee Ready Education Environment Measure'Instrument. JY P, 2016;8(3): 266-74.

32. Al-Ayed I M, Sheik SA. Assessment of the educational environment at the College of Medicine of King Saud University, Riyadh. E M H J, 2008;14,(4): 953.

33. Al-Qahtani M F. Associations between approaches to study, the learning environment, and academic achievement. J T U Med Sc, 2015 ; 10(1): 56-65.

34. Ganvir S, \& Ganvir S. Students' perception about the educational environment in a physiotherapy college in India using DREEM Questionnaire. JETHS , 2016;3(3):122-7.

35. Nouh T, Anil S, Alanazi A, Al-shehri W, Alfaisal N, Alfaris B, Alamer E. Assessing correlation between students perception of the learning environment and their academic performance. J P M A, 2016; 66(12):1616-20.

36. Baig A U, Ahmed S H, Rizvi M, Ilyas M A, Ahmed M, Rehmani, M S \& Ilyas M S. Comparison of educational environment perception of Dow Medical College students with CGPA. I J R, 2015;2(9): 72-9. 